\title{
PENGARUH KUALITAS PELAYANAN DAN PERSEPSI NILAI TERHADAP KEPUASAN DAN NIAT MENGGUNAKAN KEMBALI
}

\author{
Ni Nyoman Adriani ${ }^{1}$ \\ I Gede Ketut Warmika ${ }^{2}$
}

\author{
${ }^{1,2}$ Fakultas Ekonomi dan Bisnis Universitas Udayana, Bali, Indonesia \\ E-mail:adri_buttercup@yahoo.com
}

\begin{abstract}
ABSTRAK
Tujuan Penelitian ini adalah untuk mengetahui pengaruh kualitas pelayanan dan persepsi nilai terhadap kepuasan dan niat menggunakan kembali. Penelitian ini dilakukan di Kota Denpasar dengan melibatkan 115 orang responden melalui metode non-probability sampling. Data dikumpulkan dengan melalui penyebaran kuesioner. Teknik analisis data yang digunakan adalah analisis jalur (path analisys) dan uji sobel dengan program SPSS for Windows. Berdasarkan hasil analisis ditemukan bahwa seluruh hipotesis diterima. Kualitas pelayanan berpengaruh positif dan signifikan terhadap kepuasan pelanggan, persepsi nilai berpengaruh positif dan signifikan terhadap kepuasan pelanggan, kepuasan pelanggan berpengaruh positif dan signifikan terhadap niat menggunakan kembali, kualitas pelayanan berpengaruh positif dan signifikan terhadap niat menggunakan kembali, persepsi nilai berpengaruh positif dan signifikan terhadap niat menggunakan kembali, kepuasan pelanggan memediasi pengaruh kualitas pelayanan dengan niat menggunakan kembali, kepuasan pelanggan memediasi pengaruh persepsi nilai dengan niat menggunakan kembali.
\end{abstract}

Kata kunci: kualitas pelayanan, persepsi nilai, kepuasan dan niat menggunakan kembali

\begin{abstract}
The purpose of this study was to determine the effect of service quality and perceived value on satisfaction and intention to reuse. This research was conducted in Denpasar City involving 115 respondents through non-probability sampling method. Data was collected through questionnaires. The data analysis technique used is path analysis (path analisys) and sobel test with SPSS for Windows program. Based on the results of the analysis found that all hypotheses were accepted. Service quality has a positive and significant effect on customer satisfaction, perceived value has a positive and significant effect on customer satisfaction, customer satisfaction has a positive and significant effect on intention to reuse, service quality has a positive and significant effect on intention to reuse, value perception has a positive and significant effect on intention reuse, customer satisfaction mediates the effect of service quality with intention to reuse, customer satisfaction mediates the influence of perceived value with the intention of reusing.
\end{abstract}

Keywords: service quality, perceived value, satisfaction and intention to reuse 


\section{PENDAHULUAN}

Perkembangan teknologi informasi di era globalisasi saat ini sangat pesat. Internet adalah salah satu kemajuan teknologi yang saat ini terus berkembang. Survei yang dilakukan oleh Asosiasi Penyelenggara Jasa Internet Indonesia (APJII) mengungkapkan bahwa lebih dari setengah penduduk Indonesia kini telah terhubung ke internet. Survey yang telah dilakukan sepanjang tahun 2016 menemukan bahwa 132,7 juta orang Indonesia atau 51 persen telah terhubung internet dan meningkat pada tahun 2017 sebesar 143,26 juta orang atau 54,68 persen dengan jumlah penduduk 262 juta jiwa. Berdasarkan wilayah geografis, masyarakat Jawa paling banyak terpapar internet yakni 57,70 persen. Selanjutnya Sumatera 19,09 persen, Sulawesi 6,73 persen, Bali-Nusa 5,63 persen dan MalukuPapua 2,49 persen. Rata-rata media yang digunakan masyarakat indonesia untuk mengakses internet adalah menggunakan perangkat genggam dan komputer sebesar 50,7 persen, mengakses melalui smart phone sebesar 47,6 persen dan mengakses dari komputer sebesar 1,7 persen (Kompas.com).

Internet mempermudah masyarakat dalam mencari informasi di era globalisasi seperti saat ini. Informasi bisa diperoleh dari seluruh penjuru dunia tanpa mengenal batas waktu dan geografis (Sujana dan Sri Suprapti, 2016). Hal ini menjadikan internet sebagai kebutuhan yang tidak terlepas dari kehidupan sehari-hari. Seiring berjalannya waktu internet tidak hanya dimanfaatkan sebagai media untuk mencari informasi dan berkomunikasi, melihat pertumbuhan pengguna internet di indonesia yang mengalami peningkatan dari tahun ketahun 
dijadikan sebuah peluang usaha bagi industri inovatif yang berbasis internet. Salah satu perusahaan tersebut adalah PT. Go-Jek Indonesia.

PT.Go-Jek Indonesia adalah salah satu pioneer transportasi berbasis sistem informasi internet di Indonesia. Bermula di tahun 2010 sebagai perusahaan jasa transportasi roda dua melalui panggilan telepon, Go-Jek kini telah tumbuh menjadi on-demand mobile platform dan aplikasi terdepan yang menyediakan berbagai layanan lengkap mulai dari layanan transportasi roda dua atau Go-Ride, Go-Car layanan roda empat dan berbagai layanan on-demand lainnnya seperti Go-Food, Go-Send, Go-Mart, Go-Box, Go-Med dan Go-Life. PT. Go-Jek Indonesia kini resmi bekerjasama dengan ojek yang berada di 50 kota di Indonesia, antara lain di kota Jakarta, Bandung, Surabaya, Makasar, Medan, Palembang dan Bali (www.go-jek.com).

Hadirnya Go-Jek telah memberikan berbagai kemudahan bagi masyarakat di beberapa kota yang disinggahinya. Go-Jek menjadi salah satu solusi yang dapat membantu memenuhi kebutuhan masyarakat dengan berbagai layanan jasa yang dimiliki.Minat masyarakat cukup tinggi dalam menggunakan jasa Go-Jek, dimana layanan yang dimiliki Go-Jek dipakai secara aktif oleh 15 juta orang setiap minggunya dan para weekly active user ini dilayani sekitar 900.000 mitra pengemudi Go-Jek (Kompas.com). Kesuksesan Go-jek sebagai market leader transportasi online di Indonesia memicu munculnya pelaku bisnis yang sejenis. Selain Go-jek yang berperan dalam transportasi online, ada beberapa perusahaan transportasi online yang berperan dalam masyarakat seperti Grab dan Uber yang berdampak pada ketatnya persaingan. 
Persaingan yang ketat pada industri trasnportasi online, mengharuskan masing-masing perusahaan untuk berlomba menarik minat pelanggan dengan menyediakan berbagai fasilitas dan pelayanan yang terbaik sebagai wujud kualitas pelayanan (Bayuningrat dan Widayanto 2013). Keberhasilan kualitas jasa yang diberikan tergantung pada penilaian pelanggan atas kualitas jasa yang diberikan. Jika pelayanan yang diberikan sesuai dengan harapannya maka pelangganakan merasa puas dan mempengaruhi untuk menggunakan kembali jasa Go-Jek. Go-Jek mendapatkan peringkat pertama dalam top brand award sebagai jasa transportasi online di Indonesia. Namun berdasarkan mind share, market share dan commitment share,top brand indexGo-Jek mengalami penurunan. Tabel 1 menunjukkan tingkat top brandjasa transportasi online.

Tabel 1.

Jasa Transportasi Online Top Brand Tahun 2016

\begin{tabular}{ccc}
\hline Merk & Thn 2016(\%) & Thn 2017 (\%) \\
\hline Go-Jek & 80,8 & 59,2 \\
Grab & 14,7 & 28,2 \\
Uber & 1,7 & 8,0 \\
Lainnya & 0,7 & 0,3 \\
\hline Sumber: top brand-award com 2016 & &
\end{tabular}
Sumber: top brand-award.com, 2016

Berdasarkan data yang didapat dari Top Brand Award persentase brand pada tahun 2016 hingga 2017 menunjukan bahwa Go-Jek mampu bertahan sebagai pemimpin dalam katagori transportasi online. Go-Jek memiliki top brand index tertinggi selama dua tahun terakhir di indonesia, yaitu pada tahun 2016 sebesar 80,8 persen, namun pada tahun 2017 mengalami penurun sebesar 21,6 persen menjadi 59,2 persen sedangkan Grab dan Uber sebagai kompetitor Go-Jek terus mengalami peningkatan. 
Ni Nyoman Adrianidan I Gede Ketut Warmika. Pengaruh Kualitas Pelayanan.....

Studi pendahuluan dilakukan berupa wawancara tidak terstruktur terhadap 15 pelanggan Go-Jek. Pertanyaan yang diajukan berupa menanyakan tanggapan serta keluhan yang dirasakan ketika menggunakan jasa Go-Jek. Hasil dari studi tersebut menunjukkansebanyak 9 dari 15 orang pelanggan Go-Jek mengalami ketidakpuasan atas pelayanan yang diberikan. Salah satu keluhan yang dialami pelanggan Go-Jek yaitu driver Go-Jek yang kurang tanggap terhadap keluhan yang disampaikan pelanggan, susah mendapatkan driver bila kondisi cuaca hujan, kurang ramahnya driver Go-Jek dalam melayani pelanggan dan dari segi aplikasi beberapa pelangganmengeluh sering error bila membayar menggunakan Go-Pay.

Keluhan yang disampaikan oleh pelanggan tersebut menjadikan tantangan bagi pengelola jasa Go-Jek. Menurut Aryani dan Rosita (2010) terdapat pengaruh yang kuat dan positif antara kualitas pelayanan terhadap kepuasan pelanggan yang akan mempengaruhi minat konsumen dalam menggunakan jasa di masa yang akan datang. Agar tetap bisa bertahan dalam persaingan tentunya perusahaan harus memberikan kepuasan kepada konsumen melalui kualitas pelayanan yang diberikan.

Kualitas pelayanan adalah setiap tindakan di dalam suatu kegiatan yang dapat ditawarkan ke suatu pihak untuk pihak lain, dimana semua pada dasarnya tidak berwujud dan tidak berdampak mengakibatkan kepemilikan apapun (Kotler, 2002:83). Kualitas pelayanan sangat mempengaruhi konsumen karena dengan kualitas pelayanan yang baik maka respon balik ke pada perusahaan akan baik juga. MenurutCatherine et al. (2012) kualitas pelayanan merupakan upaya pemenuhan kebutuhan dan keinginan konsumen serta ketepatan dalam 
mengimbangi harapan konsumen. Suryadharma dan Nurcahya (2015) menyatakan kualitas pelayanan yang terdiri atas lima dimensi yaitu kehandalan, bukti fisik, daya tanggap, jaminan dan empati secara simultan berpengaruh signifikan pada kepuasan pelanggan. Menurut Astuti (2013) kualitas pelayanan mampu memberikan suatu dorongan kepada pelanggan untuk menjalin ikatan atau hubungan yang kuat dengan perusahaan.

Menurut Suariedewi dan Sulistyawati (2016) memberikan kualitas pelayanan yang baik akan berdampak pada perceived value pelanggan yang semakin tinggi.Ketika pelanggan menerima kualitas pelayanan yang lebih baik dari biaya yang dikeluarkannya, mereka percaya menerima nilai yang sangat baik (good value), dimana hal ini akan meningkatkan loyalitasnya kepada penyedia jasa (Delgado dan Munuera, 2001).Nilai yang dirasakan atau perceived valuemerupakan penilaian pelanggan terhadap manfaat produk atau jasa secara keseluruhan mengenai keuntungan yang diperoleh dan biaya yang dikeluarkan untuk mendapatkan produk atau jasa (Hellier et al., 2003). Perceived value merupakan variabel penting dan berpengaruh signifikan pada niat untuk mengunjungi atau menggunakan kembali jasa (Raza et al., 2012). Hasil penelitian Hume \& Gillian (2008), menyatakan bahwa persepsi nilai berpengaruh signifikan terhadap minat pembelian ulang. Namun hasil penelitain dari Anggreni (2015) berjudul "Pengaruh Perceived Value Terhadap Kepuasan dan Minat Beli Ulang Pelanggan Pasar Umum Ubud" menunjukkan tidak ada pengaruh signifikan perceived value terhadap repurchase intension. Dimana nilai yang dirasakan pelanggan menjadi pertimbangan minat seorang pelanggan untuk berbelanja 
kembali tetapi bukan menjadi faktor utama yang menentukan seorang pelanggan memiliki minat yang kuat untuk berbelanja kembali pada pasar umumUbud.

Menurut Anoraga (2000) minat beli ulang merupakan minat yang didasarkan atas pengalaman pembelian yang telah dilakukan di masa lalu. Menurut Lam et al. (2009) ketika keinginan dan harapan pelanggan dapat terpenuhi akan mengakibatkan terjadinya pembelian ulang atau kesetiaan yang berlanjut. Kepuasan merupakan salah salah satu faktor yang mampu mempengaruhi perilaku konsumen untuk melakukan pembelian kembali di waktu yang akan datang. Kepuasan pelanggan berhubungan erat dengan loyalitas pelanggan, dalam hal ini untuk mencapai tahap loyalitas pelanggan diwajibkan merasakan kepuasan yang diberikan oleh perusahaan penyedia jasa (Bowen dan Chen, 2001). Singh dan Thakur (2012) menyatakan bahwa kepuasan adalah perasaan seseorang dari kesenangan atau kekecewaan yang timbul dari apa yang telah diterima membandingkan apa yang dirasakan dalam kaitannya dengan harapan.

Manjunath dan Alregowda (2013) menyatakan elemen penting dalam menciptakan kepuasan dan menciptakan sikap loyal pelanggan adalah kualitas pelayanan. Menurut Aditya dan Kusumadewi (2017)kualitas pelayanan berpengaruh positif dan signifikan terhadap kepuasan pelanggan. Hasil penelitian tersebut menunjukkan bahwa semakin baik kualitas pelayanan yang diberikan maka timbul rasa puas pelanggan terhadap perusahaan. Hasil penelitian ini didukung oleh penelitan yang dilakukan Chanming dan Jianjun (2011) dalam penelitiannya juga menunjukkan hasil bahwa kualitas layanan juga memiliki 
pengaruh yang positif terhadap kepuasan pelanggan. Penelitian yang dilakukan oleh Ardani dan Suprapti (2012), dalam penelitiannya pada pasien rumah sakit juga menemukan adanya pengaruh yang positif dan signifikan, antara kualitas layanan jasa terhadap kepuasan yang diterima pelanggan. Wendha, dkk (2013) menyatakan kualitas layanan berpengaruh positif dan signifikan terhadap kepuasan pelanggan Garuda Indonesia. Berdasarkan uraian diatas, maka dapat dibuat hipotesis sebagai berikut:

$\mathrm{H}_{1}$ : Kualitas pelayanan berpengaruh positif dan signifikan terhadap kepuasan.

Hellier et al. (2003) menyatakan variabel perceived value atau nilai yang dirasakan merupakan penilaian konsumen terhadap manfaat produk secara keseluruhan mengenai keuntungan yang didapatkan dari produk serta biaya untuk memperoleh produk. Semakin tinggi perceived value konsumen, maka kepuasan konsumen juga akan semakin meningkat. Menurut Suariedewi dan Eka Sulistyawati(2016) perceived value berpengaruh positif dan signifikan terhadap kepuasan konsumen, yang menunjukkan pemberian perceived value yang baik kepada konsumen akan semakin meningkatkan kepuasan konsumen Kedai Cafeetory. Penelitian yang dilakukan oleh Mardikawati dan Farida (2013) mengenai penumpang dalam menggunakan bus efisiensi menunjukan bahwa nilai pelanggan berpengaruh positif dan signifikan terhadap kepuasan pelanggan.

$\mathrm{H}_{2}$ : Persepsi nilai berpengaruh positif dan signifikan terhadap kepuasan.

Delgado dan Munuera (2001) mengemukakan bahwa ketika konsumen menerima kualitas pelayanan yang lebih baik dari biaya yang dikeluarkannya, mereka percaya menerima nilai yang sangat baik (good value), dimana hal ini 
akan meningkatkan loyalitasnya kepada penyedia jasa. Hasil penelitian Komaling dan Alit Suryani (2017) membuktikan bahwa ada pengaruh positif Kualitas Pelayanan terhadap Niat Menggunakan Kembali Jasa transportasi Taksi Blue Bird,dimana semakin baik kualitas pelayanan, maka minat menggunakan kembali semakin meningkat. Hasil penelitian ini sejalan dengan penelitian sebelumnya yang dilakukan oleh Faradiba dan Astuti (2013) dan Kim et al. (2012) yang menyatakan bahwa kualitas pelayanan berpengaruh positif dan signifikan terhadap minat pembelian ulang.

$\mathrm{H}_{3}$ : Kualitas pelayanan berpengaruh positif dan signifikan terhadap niat menggunakan Kembali.

Jen dan Hu (2003) menguji model perceived value, yang di terapkan untuk mengidentifikasi faktor-faktor yang mempengaruhi repurchase intention pada pengguna angkutan umum. Hasil penelitian mengungkapkan repurchase intention secara signifikan di pengaruhi oleh perceived value. Hume \& Gillian (2008), menyatakan adanya hubungan yang positif antara perceived value dengan minat beli ulang. Perceived value pelanggan akan mempengaruhi keputusan pelanggan dalam melakukan pembelian atau tidak. Hasil penelitian ini sejalan dengan penelitian yang dilakukan oleh Wulandari dan Ekawati (2015)menunjukkan persepsi nilai yang dirasakan pelanggan berpengaruh positif terhadap niat menggunakan ulang.

$\mathrm{H}_{4}$ : Persepsi nilai berpengaruh positif dan signifikan terhadap niat menggunakan Kembali

Solvang (2007) menyatakan bahwa kepuasan berpengaruh signifikan dan sangat kuat terhadap niat beli ulang. Hasil penelitian ini sejalan dengan penelitian 
yang dilakukan Siyamtinah dan Hendar (2015) yang memberikan hasil bahwa variabel kepuasan secara signifikan berpengaruh positif terhadap niat pembelian ulang secara online. Hasil tersebut menunjukkan semakin konsumen puas maka akan semakin positif niat pembelian ulang secara online. Wenet al. (2011) yang memberikan hasil penelitian bahwa variabel kepuasan secara signifikan berpengaruh positif terhadap niat pembelian ulang secara online. Lin dan Lekhawipat (2014) menemukan bahwa kepuasan pelanggan berpengaruh positif dan signifikan terhadap niat membeli kembali.

$\mathrm{H}_{5}$ : Kepuasan berpengaruh positif dan signifikan terhadap niat menggunakan kembali

Menurut Saidani dan SamsulArifin (2012) menyatakan bahwa secara tidak langsung kepuasan konsumen dapat memperkuat minat beli ulang. Hal ini menunjukkan bahwa kualitas layanan dan kepuasan konsumen yang tinggi dapat meningkatkan minat beli ulang. Penelitian yang dilakukan oleh Bahar dan Sjaharuddin (2015) menyatakan bahwa kualitas pelayanan berpengaruh signifikan secara parsial terhadap minat beli ulang dan kepuasan konsumen mampu memediasi antara kualitas pelayanan terhadap minat beli ulang. Hal ini membuktikan bahwa peranan kepuasan konsumen dapat memperkuat minat beli ulang pada McDonald's Alauddin. Hasil penelitian ini sejalan dengan penelitian yang dilakukan oleh Adixio dan Laila Saleh (2013) menyatakan bahwa kualitas layanan berpengaruh positif dan signifikan terhadap niat pembelian ulang yang dimediasi oleh kepuasan pelanggan.

$\mathrm{H}_{6}$ : Kepuasan pelanggan mampu memediasi secara positif dan signifikan pengaruh kualitas pelayanan terhadap niat menggunakan kembali. 
Boone \& Kurtz (2007) mengartikan kepuasan pelanggan sebagai hasil dari barang atau jasa yang memenuhi atau melebihi kebutuhan dan harapan pembeli. Hal ini diperkuat dari hasil penelitian yang dilakukan oleh Ching-Lin dan Yuan (2015) dimana nilai pelanggan mempunyai pengaruh yang positif dan signifikan terhadap minat beli ulang baik secara langsung maupun melalui kepuasan pelanggan terlebih dahulu.

$\mathrm{H}_{7}$ : Kepuasan pelanggan mampu memediasi secara positif dan signifikan pengaruh persepsi nilai terhadap niat menggunakan kembali.

\section{METODE PENELITIAN}

Penelitian ini dilakukan di Kota Denpasar.Latar belakang pemilihan lokasi pada penelitian ini adalah Denpasar merupakan ibu kota Provinsi Bali yang memiliki tingkat penduduk yang cukup tinggi serta mobilitas yang tinggi. KotaDenpasar menjadi pusat pendidikan, perkantoran dan pusat bisnis yang menyebabkan Denpasar menjadi kota yang padat akan aktivitas yang berdampak pada kemacetan. Hadirnya Go-Jek tentu menjadi sebuah solusi bagi masyarakat Denpasar dalam membantu aktivitas dengan berbagai pelayanan jasa yang ditawarkan.

Variabel endogen dalam penelitian ini yaitu niat menggunakan kembali (Y2). Variabel mediasi dalam penelitian ini yaitu kepuasan (Y1). Variabel eksogen dalam penelitian ini yaitu kualitas pelayanan (X1) dan persepsi nilai (X2). Adapun populasi dalam penelitian ini adalah masyarakat yang berdomisili di kota Denpasar yang pernah menggunakan layanan jasa Go-Jek khususnya pengguna layanan jasa Go-Ride dan Go-Food.Penelitian inimenggunakan 23 indikator yang berarti sampel yang diperlukan minimal $115(5 \times 23)$ dan maksimal 
230 (10x23). Penelitian ini menggunakan 115 sampel responden yang berarti sudah memenuhi kriteria minimal 115 responden dan maksimal 230 responden.

Metode penentuan sampel yang digunakan pada penelitian ini adalah non probability sampling. Digunakan teknik non probability sampling karena konsumen yang pernah melakukan pembelian jasa Go-Jek di kota Denpasar tidak tersedia dalam jumlah yang pasti dan kemudian populasi akan berubah secara periodik yang tidak diketahui.

Usaha untuk memperoleh data yang dibutuhkan dalam mendukung penelitian ini, maka metode yang digunakan untuk mengumpulkan data dengan menyebar kuisioner secara online kepada responden dengan jumlah sampel sebanyak 115 sampel. Daftar pertanyaan yang diberikan kepada responden mengenai kualitas pelayanan, persepsi nilai, kepuasan dan niat menggunakan kembali pada jasa Go-Jek dan butir-butir pernyataan tersebut di ukur menggunakan skala likert.

Teknik analisis yang digunakan adalah teknik analisis jalur. Ghozali (2013:249) mendifinisikan analisis jalur (Path Analysis) adalah perluasan dari analisis regresi linear berganda dalam memperkirakan hubungan kausalitas antara variabel yang telah ditetapkan sebelumnya berdasarkan teori. Analisi jalur digunakan untuk menentukan pola hubungan antara tiga atau lebih dan tidak dapat digunakan untuk mengkonfirmasi atau menolak hipotesis.

\section{HASIL PENELITIAN DAN PEMBAHASAN}

Teknik analisis jalur digunakan sebagai teknik analisis data dalam penelitian ini. Teknik ini merupakan pengembangan lebih lanjut dari analisis 
regresi linier berganda yang menguji persamaan regresi, dimana variabel bebas dan terikat terlibat didalamnya.

Tabel 2.

Hasil Analisis Jalur Persamaan Regresi 1

\begin{tabular}{lccccc}
\hline \multicolumn{1}{c}{ Model } & $\begin{array}{c}\text { Unstandardized } \\
\text { Coefficients }\end{array}$ & Std. Error & Beta & Sig \\
& B & 0,264 & & $-2,884$ & 0,005 \\
1 ( Constant) & $-0,76$ & 0,088 & 0,645 & 9,225 & 0,000 \\
Kualitas Pelayanan & 0,813 & 0,087 & 0,263 & 3,763 & 0,000 \\
Persepsi Nilai & 0,326 & & Sig. F : 0,000 \\
R1 ${ }^{2}: 0,724$ & F hitung : 146,673 & &
\end{tabular}

Sumber: Data diolah, 2018

Berdasarkan hasil analisis jalur substruktural 1 seperti yang disajikan pada

Tabel 2 maka persamaan struktural untuk hipotesis 1 dan 2 adalah sebagai berikut:

$$
\mathrm{Y}_{1}=0,645 \mathrm{X}_{1}+0,263 \mathrm{X}_{2}+\mathrm{e}_{1}
$$

Pengaruh kualitas pelayanan terhadap kepuasan pelanggan dalam penelitian ini diperoleh nilai korelasi beta sebesar 0,645 dengan tingkat signifikansi $0,000<$ 0,05 sehingga $\mathrm{H}_{0}$ ditolak dan $\mathrm{H}_{1}$ diterima, yang mengindikasikan bahwa kualitas pelayanan berpengaruh positif dan signifikan terhadap kepuasan pelanggan. Hasil tersebut menunjukkan bahwa semakin baik kualitas pelayanan yang diberikan oleh driver Go-Jek maka akan meningkatkan kepuasan pelanggan Go-Jek.

Hasil dalam penelitian ini didukung oleh hasil dari penelitian sebelumnya yang dilakukan oleh Chanming dan Jianjun (2011), Ardani dan Suprapti (2012), dan Wendha dkk. (2013) yang menyatakan bahwa kualitas layanan berpengaruh positif dan signifikan terhadap kepuasan pelanggan.

Pengaruh persepsi nilai terhadap kepuasan pelanggan dalam penelitian ini diperoleh nilai korelasi beta sebesar 0,263dengan tingkat signifikansi $0,000<0,05$ sehingga $\mathrm{H}_{0}$ ditolak dan $\mathrm{H}_{1}$ diterima, yang mengindikasikan bahwa persepsi nilai 
berpengaruh positif dan signifikan terhadap kepuasan pelanggan. Hasil tersebut menunjukkan bahwa semakin tinggi persepsi nilai yang dirasakan oleh pelanggan terhadap jasa yang diberikan oleh Go-Jek maka akanmeningkatkan kepuasan pelanggan dalam menggunakan jasa Go-Jek.

Hasil dalam penelitian ini didukung oleh hasil dari penelitian sebelumnya yang dilakukan oleh Hellier et al. (2003), Suariedewi dan Eka Sulistyawati (2016) dan Mardikawati dan Farida (2013) yang menyatakan bahwa persepsi nilai berpengaruh positif dan signifikan terhadap kepuasan pelanggan.

Hasil persamaan regresi 2 disajikan dalam Tabel 3 sebagai berikut:

Tabel 3.

Hasil Analisis Jalur Persamaan Regresi 2

\begin{tabular}{lccccc}
\hline \multicolumn{1}{c}{ Model } & $\begin{array}{c}\text { Unstandardized } \\
\text { Coefficients }\end{array}$ & & $\begin{array}{c}\text { Unstandardized } \\
\text { Coefficients }\end{array}$ & T & Sig \\
\hline \multicolumn{1}{c}{ 1 ( Constant) } & $-0,012$ & Std. Error & Beta & & \\
Kualitas Pelayanan & 0,453 & 0,302 & & $-0,04$ & 0,968 \\
Persepsi Nilai & 0,229 & 0,129 & 0,371 & 3,508 & 0,001 \\
Kepuasan & 0,297 & 0,101 & 0,191 & 2,225 & 0,026 \\
R2 & F hitung: $: 66,583$ & 0,308 & 2,849 & 0,005 \\
Sumber: $:$ Data & & & & Sig. F : 0,000 \\
\hline
\end{tabular}

Sumber: Data diolah, 2018

Berdasarkan hasil analisis jalur substruktur 2 telah disajikan pada Tabel 2 maka persamaan struktural untuk hipotesis 3, 4 dan 5 adalah sebagai berikut:

$$
\mathrm{Y}_{2}=0,371 \mathrm{X}_{1}+0,191 \mathrm{X}_{2}+0,308 \mathrm{Y}_{1+} \mathrm{e}_{2}
$$

Keterangan :

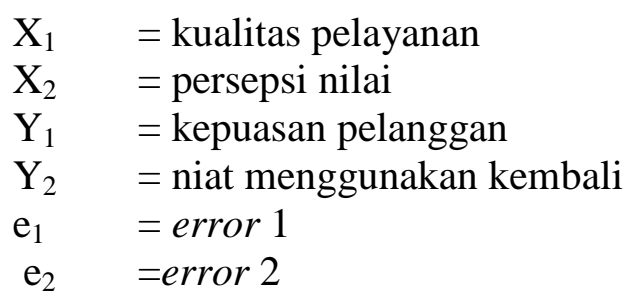


Ni Nyoman Adrianidan I Gede Ketut Warmika. Pengaruh Kualitas Pelayanan.....

Pengaruh kualitas pelayanan terhadap niat menggunakan kembali dalam penelitian ini diperoleh nilai korelasi beta sebesar 0,371dengan tingkat signifikansi $0,001<0,05$ sehingga $\mathrm{H}_{0}$ ditolak dan $\mathrm{H}_{1}$ diterima, yang mengindikasikan bahwa kualitas pelayanan berpengaruh positif dan signifikan terhadap niat menggunakan kembali. Hasil tersebut menunjukkan bahwa semakin baik kualitas pelayanan yang diberikan, maka akan mempengaruhi niat pelangan untuk menggunakan kembali jasa Go-Jek.

Hasil dalam penelitian ini didukung oleh penelitian sebelumnya yang dilakukan oleh Faradiba dan Astuti (2013), Kim et al. (2012), dan Komaling dan Alit Suryani (2017)yang menyatakan bahwa persepsi nilai berpengaruh positif dan signifikan terhadap niat menggunakan kembali.

Pengaruh persepsi nilai terhadap niat menggunakan kembali dalam penelitian ini diperoleh nilai korelasi beta sebesar 0,191dengan tingkat signifikansi $0,026<0,05$ sehingga $\mathrm{H}_{0}$ ditolak dan $\mathrm{H}_{1}$ diterima, yang mengindikasikan bahwapersepsi nilai berpengaruh positif dan signifikan terhadap niat menggunakan kembali. Hasil ini menunjukkan bahwa semakin tinggi persepsi nilai yang dirasakan pelanggan terhadap jasa yang diberikan, maka akan mempengaruhi niat pelangan untuk menggunakan kembali jasa Go-Jek.

Hasil dalam penelitian ini didukung oleh penelitian sebelumnya yang dilakukan oleh Wulandari dan Ekawati (2015) menunjukkan persepsi nilai yang dirasa pelanggan berpengaruh positif dan signifikan terhadap niat menggunakan ulang. 
Pengaruh kepuasan terhadap niat menggunakan kembali dalam penelitian ini diperoleh nilai korelasi beta sebesar 0.308dengan tingkat signifikansi $0,005<$ 0,05 sehingga $\mathrm{H}_{0}$ ditolak dan $\mathrm{H}_{1}$ diterima, yang mengindikasikan bahwa kepuasan pelanggan berpengaruh positif dan signifikan terhadap niat menggunakan kembali. Hasil tersebut menunjukkan bahwa semakin tinggi tingkat kepuasan yang dirasakan pelanggan, maka akan mempengaruhi niat pelanggan untuk menggunakan kembali jasa Go-Jek.

Hasil dalam penelitian ini didukung oleh penelitian sebelumnya yang dilakukan oleh Siyamtinah dan Hendar (2015), Wenet al. (2011), Lin dan Lekhawipat (2014) menunjukkan persepsi nilai yang dirasa pelanggan berpengaruh positif dan signifikan terhadap niat menggunakan kembali.

Berdasarkan persamaan regresi 1 dan 2 diketahui nilai $R_{1}{ }^{2}=0,724$ dan $R_{2}^{2}$ $=0,643$ maka nilai error untukmasing-masing persamaan di hitung sebagai berikut:

$$
\begin{array}{lll}
\mathrm{e} & =\sqrt{1-k 1^{2}} \ldots \ldots \ldots \ldots \ldots \ldots \ldots \ldots \ldots \ldots \ldots \ldots \ldots \ldots \ldots \ldots \ldots \ldots \ldots \ldots \ldots \ldots \ldots \\
\mathrm{e}_{1} & =\sqrt{1-k 1^{2}}=\sqrt{1-0,724}=0,525 \\
\mathrm{e}_{2} & =\sqrt{1-k 2^{2}}=\sqrt{1-0,643}=0,597
\end{array}
$$

Berdasarkan perhitungan di atas, diketahui besarnya pengaruh $\mathrm{e}_{1}=0,525$. Sebesar 0,525 varian kepuasan pelanggan tidak dijelaskan oleh variabel kualitas pelayanan dan persepsi nilai. Nilai dari $\mathrm{e}_{2}=0,597$. Sebesar 0,597 varian niat menggunakan kembali tidak dijelaskan oleh variabel kualitas pelayanan dan persepsi nilai dan kepuasan pelanggan. Berdasarkan perhitungan error $\left(\mathrm{e}_{1}\right.$ dan $\left.\mathrm{e}_{2}\right)$ yang telah diketahui maka koefisien determinasi total dapat dihitung sebagai berikut: 


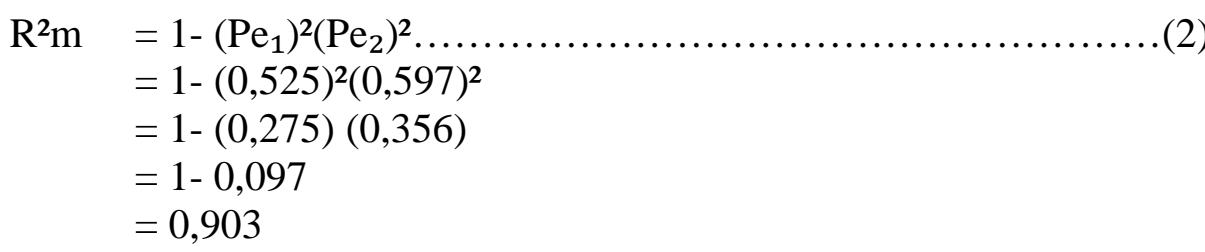

Nilai koefisien determinasi total sebesar 0,903 yang berarti bahwa sebesar 90,3 persen variasi niat menggunakan kembali dipengaruhi oleh variasi kualitas pelayanan, persepsi nilai dan kepuasan pelanggan sedangkan sisanya sebesar 9,7 persen dijelaskan oleh faktor lain yang tidak dimasukkan dalam model.

Hasil pada Tabel 1 menunjukkan nilai koefisien sig. F adalah 0,000. Nilai koefisien ini lebih kecil dari 0,05 sehingga dapat disimpulkan bahwa kualitas pelayanan, persepsi nilai secara signifikan mampu mempengaruhi kepuasan pelanggan. Hasil pada Tabel 2 menunjukkan nilai koefisien sig. F adalah 0,000. Nilai koefisien ini lebih kecil dari 0,05 sehingga dapat disimpulkan bahwa kualitas pelayanan, persepsi nilai dan kepuasan pelanggan secara signifikan mampu mempengaruhi niat menggunakan kembali. Nilai koefisien sebesar 0,000 menggambarkan bahwa model persamaan struktural 1 dan 2 telah memenuhi syarat Goodness of fit melalui uji F.

Tabel 4.

Pengaruh Langsung, Pengaruh Tidak Langsung serta Pengaruh Total

\begin{tabular}{lccc}
$\begin{array}{l}\text { Pengaruh } \\
\text { Variabel }\end{array}$ & $\begin{array}{c}\text { Pengaruh } \\
\text { Langsung }\end{array}$ & $\begin{array}{c}\text { Pengaruh tidak langsung melalui Kepuasan } \\
\text { Pelanggan }\end{array}$ & $\begin{array}{c}\text { Pengaruh } \\
\text { Total }\end{array}$ \\
\hline $\mathrm{X} 1 \longrightarrow \mathrm{Y} 1$ & 0,645 & - & 0,645 \\
$\mathrm{X} 2 \longrightarrow \mathrm{Y} 1$ & 0,263 & - & 0,263 \\
$\mathrm{X} 1 \longrightarrow \mathrm{Y} 2$ & 0,371 & 0,198 & 0,569 \\
$\mathrm{X} 2 \longrightarrow \mathrm{Y} 2$ & 0,191 & 0,081 & 0,272 \\
$\mathrm{Y} 1 \longrightarrow \mathrm{Y} 2$ & 0,308 & - & 0,308 \\
\hline
\end{tabular}


Sumber: Data diolah, 2018

Hasil pada Tabel 3 menunjukkan bahwa pengaruh langsung antara variabel kualitas pelayanan dan kepuasan pelanggan memiliki nilai pengaruh langsung sebesar 0,645. Antara persepsi nilai dengan kepuasan pelanggan memiliki nilai pengaruh langsung sebesar 0,263. Variabel kualitas pelayanan dengan niat menggunakan kembali memiliki pengaruh langsung sebesar 0,371. Antara persepsi nilai dengan niat menggunakan kembali dengan nilai pengaruh langsung sebesar 0,191. Variabel kepuasan pelanggan dengan variabel niat menggunakan kembali memiliki pengaruh secara langsung sebesar 0,308 .

Pengaruh tidak langsung antara variabel kualitas pelayanan terhadap niat menggunakan kembali melalui kepuasan pelanggan sebesar 0,198, dan antara variabel persepsi nilai terhadap niat menggunakan kembali melalui kepuasan pelanggan sebesar 0,081. Hal ini menunjukkan bahwa pengaruh kualitas pelayanan dan persepsi nilai terhadap niat menggunakan kembali akan meningkat apabila dimediasi oleh kepuasan pelanggan.

Selain terdapat pengaruh langsung dan tidak langsung antara variabel didalam penelitian ini terdapat pula pengaruh total yang menunjukkan jumlah pengaruh dari berbagai hubungan. Pengaruh total adalah penjumlahan dari pengaruh langsung dan tidak langsung. Pada tabel 3 variabel kepuasan pelanggan sebagai variabel mediasi meningkatkan pengaruh kualitas pelayanan sehingga pengaruh totalnya menjadi 0,569 dan sisanya 0,431 dijelaskan oleh variabel lain. Variabel persepsi nilai terhadap niat menggunakan kembali dimediasi oleh 
Ni Nyoman Adrianidan I Gede Ketut Warmika. Pengaruh Kualitas Pelayanan.....

kepuasan pelanggan memiliki pengaruh total sebesar 0,272 dan sisanya sebesar 0,728 dijelaskan oleh variabel lain.

Uji Sobel dilakukan untuk menguji signifikansi hubungan tidak langsung variabel kualitas pelayanan $\left(\mathrm{X}_{1}\right)$ dan persepsi nilai $\left(\mathrm{X}_{2}\right)$ terhadap variabel niat menggunakan kembali $\left(\mathrm{Y}_{2}\right)$ melalui variabel kepuasan $\left(\mathrm{Y}_{1}\right)$. Uji sobel dihitung dengan menggunakan aplikasi Microsoft Excel 2010. Nilai koefisien z jika lebih besar dari 1,96, maka variabel kupuasan pelanggan memediasi pengaruh kualitas pelayanan dan persepsi nilai terhadap niat menggunakan kembali. Uji sobel dihitung dengan persamaan sebagai berikut:

Peran Kepuasan Pelanggan dalam memediasi Pengaruh Kualitas Pelayanan terhadap Niat Meggunakan Kembali dihitung dalam rumus di bawah ini:

Keterangan:

$$
\begin{aligned}
& =0,645 \\
& \mathrm{Sa}=0,088 \\
& \mathrm{~b}=0,308 \\
& \mathrm{Sb}=0,104 \\
& Z=\frac{a}{\sqrt{b^{2} S u^{2}+u^{2} S b^{2}+S u^{2} S b^{2}}} . \\
& \mathrm{Z}=\frac{(0,6 \quad)(0,3 \quad)}{\sqrt{(0,3 \quad)^{2}(0,0 \quad)^{2}+(0,6 \quad)^{2}(0,1 \quad)^{2}+(0,0 \quad)^{2}(0,1 \quad)^{2}}} \\
& \mathrm{Z}=\frac{0,1}{\sqrt{0,0 \quad+0,0 \quad+0,0}} \\
& Z=2,7242
\end{aligned}
$$

Berdasarkan perhitugan yang telah dilakukan tersebut, diperoleh nilai $\mathrm{Z}$ sebesar 2,7242> 1,96 ini berarti variabel mediasi yaitu variabel kepuasan 
pelanggan secara signifikan memediasi kualitas pelayanan terhadap niat menggunakan kembali.

Peran kepuasan pelanggan dalam memediasi pengaruh kualitas pelayanan terhadap niat menggunakan kembali pada pelanggan Go-jek telah diuji dalam penelitian ini.Hasil uji pengaruh kualitas pelayanan terhadap niat menggunakan kembali semula bernilai0.371, kemudian setelah adanya kepuasan pelanggan sebagai variabel mediasi, nilai pada pengaruh kualitas pelayanan terhadap niat menggunakan kembali meningkat menjadi sebesar 0,569. Hasil tersebut menunjukkan bahwa kepuasan pelanggan memediasi pengaruh kualitas pelayanan terhadap niat menggunakan kembali. Uji sobel yang telah dihitung memperkuat hasil tersebut dengan nilai koefisien z yang diperoleh adalah $2.724>1,96$ dengan tingkat signifikansi $0,000<0,05$ sehingga $\mathrm{H}_{0}$ ditolak dan $\mathrm{H}_{1}$ diterima, yang mengindikasikan bahwa kepuasan pelanggan dinilai mampu memediasi pengaruh kualitas pelayanan terhadap niat menggunakan kembali.

Hasil penelitian ini didukung oleh penelitian yang dilakukan oleh Bahar dan Sjaharuddin (2015), Adixio dan Laila Saleh (2013) menyatakan bahwa kualitas layanan berpengaruh positif signifikan terhadap niat pembelian ulang yang dimediasi oleh kepuasan pelanggan.

Peran Kepuasan Pelanggan dalam memediasi Pengaruh Persepsi Nilai terhadap Niat Meggunakan Kembali dihitung dalam rumus di bawah ini:

\section{Keterangan:}

$$
\begin{array}{r}
=0,263 \\
\mathrm{Sa}=0,087
\end{array}
$$


$\mathrm{b}=0,308$

$\mathrm{Sb}=0,104$

$$
\begin{aligned}
& \mathrm{Z}=\frac{a}{\sqrt{0^{2} S u^{2}+u^{2} S b^{2}+S u^{2} S b^{2}}} \\
& Z=\frac{(0,2 \quad(0,3 \quad)}{\sqrt{(0,3 \quad)^{2}(0,0 \quad)^{2}+(0,2)^{2}(0,1 \quad)^{2}+(0,0 \quad)^{2}(0,1 \quad)^{2}}} \\
& Z=\frac{0,0 \quad}{\sqrt{0,0 \quad+0,0 \quad+0,0}} \\
& Z=2,0588
\end{aligned}
$$

Berdasarkan perhitugan yang telah dilakukan tersebut, diperoleh nilai $\mathrm{Z}$ sebesar 2,0588> 1,96 ini berarti variabel mediasi yaitu variabel kepuasan pelanggan secara signifikan memediasi persepsi nilai terhadap niat menggunakan kembali.

Peran kepuasan pelanggan dalam memediasi pengaruh persepsi nilai terhadap niat menggunakan kembali pada pelanggan Go-jek telah diuji dalam penelitian ini.Hasil uji pengaruh persepsi nilai terhadap niat menggunakan kembali semula bernilai 0,191 kemudian setelah adanya kepuasan pelanggan sebagai variabel mediasi, nilai pada pengaruh persepsi nilai terhadap niat menggunakan kembali meningkat menjadi sebesar 0,272. Hasil tersebut menunjukkan bahwa kepuasan pelanggan memediasi pengaruh kualitas pelayanan terhadap niat menggunakan kembali. Uji sobel yang telah dihitung memperkuat hasil tersebut dengan nilai koefisien z yang diperoleh adalah 2,058 > 1,96 dengan tingkat signifikansi $0,000<0,05$ sehungga $\mathrm{H} 0$ ditolak dan $\mathrm{H} 1$ diterima, yang mengindikasikan bahwa kepuasan pelanggan dinilai mampu memediasi pengaruh persepsi nilai terhadap niat menggunakan kembali. 
Hasil penelitian ini didukung oleh penelitian yang dilakukan oleh Ching-Lin dan Yuan (2015)menyatakan bahwa persepsi nilai berpengaruh positif signifikan terhadap niat pembelian ulang yang dimediasi oleh kepuasan pelanggan.

Implikasi dari hasil penelitian ini dibagi menjadi dua bagian, yaitu implikasi teoritis dan implikasi praktis. Implikasi teoritis adalah hal-hal yang perlu dilakukan peneliti berikutnya dalam rangka mengembangkan hasil penelitian ini, sedangkan implikasi praktis adalah hal-hal yang perlu diperhatikan terkait pelaku bisnis khususnya Go-Jek berkaitan dengan hasil penelitian.

Dalam rangka pengembangan teori tentang perilaku pelanggan pada jasa Go-Jek, bagi peneliti diharapkan menambahkan indikator yang belum dimasukan dalam variabel penelitian ini baik yang mempengaruhi kualitas pelayanan, persepsi nilai maupun yang mempengaruhi kepuasan pelanggan pada niat menggunakan kembali jasa Go-Jek, ukuran sampel sebaiknya ditingkatkan sehingga hasilnya bisa lebih representatif.

Berdasarkan data responden yang secara langsung adalah pengguna layanan Go-Jek dapat dilihat bahwa semua variabel yaitu kualitas pelayanan, persepsi nilai dan kepuasan pelanggan menunjukkan bahwa hasil yang didapat setiap variabel positif dan signifikan. Ini membuktikan bahwa responden mempertimbangkan faktor kualitas pelayanan, persepsi nilai dan tingkat kepuasannya untuk tetap menggunakan jasa Go-Jek. Hal ini merupakan langkah selanjutnya agar pihak manajemen Go-Jek meningkatkan kualitas pelayanan yang dapat meninggkatkan persepsi nilai pelanggan sehingga mampu membentuk kepuasan pelanggan yang 
positif yang akan merangsang pelanggan untuk memutuskan menggunakan kembali jasa Go-Jek.

Bedasarkan penelitian yang telah dilakukan, terdapat beberapa hal yang menjadi keterbatasan didalam penelitian ini. Adapun keterbatasan yang dapat diuraikan yaitu waktu yang cukup singkat dalam melakukan penelitan ini, sedangkan lingkungan, trend dan kebiasaan dapat berubah setiap saat, sehingga penelitian ini penting untuk dilakukan kembali. Ruang lingkup penelitian ini terbatas pada wilayah Kota Denpasar, sehingga hasil penelitian ini tidak dapat digeneralisasikan untuk pelanggan di luar wilayah Kota Denpasar.

\section{SIMPULAN DAN SARAN}

Berdasarkan hasil pembahasan, dapat ditarik beberapa simpulan bahwa kualitas pelayanan berpengaruh positif dan signifikan terhadap kepuasan pelanggan. Hasil penelitian menunjukkan bahwa semakin baik kualitas pelayanan yang diberikan, maka kepuasan pelanggan akan semakin meningkat pada jasa GoJek di Kota Denpasar.

Persepsi nilai berpengaruh positif dan signifikan terhadap kepuasan pelanggan. Hasil penelitian menunjukkan bahwa semakin baik persepsi nilai yang dirasakan maka kepuasan pelanggan akan semakin meningkat pada jasa Go-Jek di Kota Denpasar.

Kepuasan pelanggan berpengaruh positif dan signifikan terhadap niat menggunakan kembali. Hasil penelitian menunjukkan bahwa semakin tinggi tingkat kepuasan pelanggan terhadap jasa Go-Jek maka semakin meningkat niat menggunakan kembali pelanggan Go-Jek di Kota Denpasar. 
Kualitas pelayanan berpengaruh positif dan signifikan terhadap niat menggunakan kembali. Hasil penelitian menunjukkan bahwa semakin baik kualitas pelayanan yang diberikan, maka semakin tinggi niat menggunakan kembali pelanggan Go-Jek di Kota Denpasar.

Persepsi nilai berpengaruh positif dan signifikan terhadap niat menggunakan kembali. Hasil penelitian menunjukkan bahwa semakin tinggi persepsi nilai yang dirasakan pelanggan, maka semakin tinggi niat menggunakan kembali pelanggan Go-Jek di Kota Denpasar.

Kepuasan pelanggan mampu memediasi pengaruh kualitas pelayanan terhadap niat menggunakan kembali secara positif dan signifikan. Hasil penelitian menunjukkan bahwa kekuatan kepuasan pelanggan turut mempengaruhi dan menentukan pengaruh kualitas pelayanan terhadap niat menggunakan kembali jasa Go-Jek di Kota Denpasar.

Kepuasan pelanggan mampu memediasi pengaruh persepsi nilai terhadap niat menggunakan kembali secara positif dan signifikan. Hasil penelitian menunjukkan bahwa kekuatan kepuasan pelanggan turut mempengaruhi dan menentukan pengaruh persepsi nilai terhadap niat menggunakan kembali jasa GoJek di Kota Denpasar.

Berdasarkan hasil analisis dan simpulan, maka saran yang dapat diberikan adalah tanggapan responden pada variabel kualitas pelayanan memperlihatkan indikator terendah yaitu penampilan driver Go-Jek selalu rapi, namun indikator tersebut masuk kedalam kategori baik. Saran bagi pihak Go-Jek driver Go-Jek diharapkan agar berpenampilan sesuai dengan standar yang telah ditetapkan 
perusahaan, seperti jaket dan helm yang berisi logo Go-Jek agar tetap digunakan saat melayani pelanggan, sehingga pelanggan tetap merasa nyaman dan mudah mengenali driver Go-Jek saat menggunakan jasa Go-jek.

Tanggapan responden pada variabel persepsi nilai memperlihatkan indikator terendah yaitu emotional value yaitu perasaan senang setelah menggunakan jasa Go-Jek karena kebutuhan mobilitas pelanggan dapat terpenuhi, namun indikator tersebut masuk kedalam kategori baik. Saran bagi pihak Go-Jek agar memberikan potongan harga kepada pelanggan yang loyal, memberikan pelayanan yang sesuai dengan biaya yang dikeluarkan dan driver Go-Jek selalu menanyakan kebutuhan perjalaanan pelanggan pada saat menggunakan jasa Go-Ride.

Tanggapan responden pada variabel kepuasan memperlihatkan indikator terendah yaitu tidak memiliki keluhan setiap kali menggunakan jasa Go-Jek, namun indikator tersebut masuk kedalam kategori baik. Saran bagi pihak Go-Jek diharapkan dapat meningkatkan kualitas pelayanan, baik dari segi aplikasi maupun dari pelayanan yang diberikan oleh driver Go-Jek serta menyediakan layanan pengaduan dalam aplikasi Go-Jek agar pelanggan mudah menyampaikan keluhan dan saran terhadap pelayanan jasa Go-Jek.

Tanggapan responden pada variabel niat menggunakan kembali memperlihatkan indikator terendah yaitu tidak akan berpindah, namun indikator tersebut masuk kedalam kategori baik. Saran bagi pihak Go-Jek diharapkan terus melakukan inovasi dan pengembangan fitur mengingat kebutuhan pelanggan yang semakin hari semakin beragam sehingga dapat meningkatkan minat pelangan untuk tetap memilih menggunakan kembali jasa Go-Jek. 
Bagi penelitian selanjutnya, diharapkan dapat menambah variabel lain yang berpengaruh terhadap kepuasan dan niat menggunakan kembali. Selain itu dengan melibatkan responden yang lebih banyak akan menghasilkan hasil yang lebih akurat.

\section{REFERENSI}

Aditya, Made Purwa dan Made Wulandari Kusumadewi.(2017). Peran Kepuasan dalam Memediasi Pengaruh Kualitas Pelayanan terhadap Loyalitas Pelanggan.E-Jurnal Manajemen Unud. 6(9), hal. 5061-5087.

Adixio, RikoFirmawandanLailaSaleh.(2013). PengaruhKualitas Layanan Dan Nilai yang dirasakanTerhadapNiatPembelianUlangMelaluiMediasiKepuasanPelanggan Restoran Solaria Di Surabaya.Journal of Business and Banking. 3 (2), hal. 151-164.

Anoraga, P. (2000). Manajemen bisnis. Jakarta: PT Rineka Cipta.

Anggreni, Putri. (2015). Pengaruh Perceived Value Terhadap Kepuasan Dan Minat Beli Ulang Pelanggan Pasar UmumUbud. Jurnal Telaah Bisnis. 16(2), hal. 115.

Ardani, Wayan dan Ni Wayan Sri Suprapti.(2012). Pengaruh Kualitas Layanan terhadap Kepuasan dan WOM (Studi di RSUD Wangaya Denpasar).EJurnal Manajemen Unud. 1(2), hal. 240-254.

Aryani, Dwi., Rosinta, Febrina. (2010). Pengaruh Kualitas Layanan terhadap Kepuasan Pelanggan dalam Membentuk Loyalitas Pelanggan. Jurnal Ilmu Administrasi Dan Organisasi, Vol. 17, No. 2, Hal. 114-126.

Astuti, Tri dan Rr. Indah Mustikawati. (2013). Pengaruh Perepsi Nasabah Tentang Tingkat Suku Bunga, Promosi Dan Kualitas Pelayanan Terhadap Minat Menabung Nasabah. Jurnal Nominal. 2(1), hal 182-198.

Bahar, Arfiani dan Herman Sjaharuddin.(2015). Pengaruh Kualitas Produk dan Kualitas Pelayanan Terhadap Kepuasan Konsumen Terhadap Niat Beli Ulang.Jurnal Organisasi dan Manajemen. 3(1), hal. 14-34.

Bayuningrat, Handoko dan Widayanto. (2013). Pengaruh Kualitas Pelayanan Kualits Produk, dan Kepuasan pelanggan Terhadap Loyalitas Pengguna Jasa 
Transportasi Taksi New Atlas Kota Semarang. Journal of Social and Politic. 3(1), hal. 2-4.

Boone, L., \& Kurtz, D. (2007). Pengantar Bisnis Konteporer. Edisi Sebelas, Jakarta: Salemba Empat

Bowen, J.T. and Chen, S.L. (2001). The Relationship Between Customer Loyalty and Customer Satisfaction. Journal of Contemporary Hospitality Management. 13(5), pp. 213-7.

Catherine, Tan Yein Ping, Norazah, Moh. Suki and Norbayah, Mond Suki. (2012). Service Quality Dimension Effect On Costumer Satisfaction Towards E-Banking. Journal of Contemporary Research in Business,4(1), pp. 364-379.

Chanming, CAO and CHEN Jianjun. (2011). An Empirical Analysis of the Relationship Amongthe Service Quality, Customer Satisfaction and Loyalty of High Speed Railway Based on Strctural Equation Model. Journalof Canadian Social Science. 7(4), pp. 67-73.

Ching-Lin, Huang and Yuan, Kao. (2015). The Influence Of Perceived Value On Repurchase Intention: A Leading 3C Retailer in Taiwan As An Example. Journal of Information Technology and Business Management. 43(1), pp. 2304-0777.

Delgado-Ballester, E and Munuera-Aleman, J. L. (2001). Brand Trust in the Context Consumer Loyalty.European Journal of Marketing. 35(11), pp. 1238-1258.

Faradiba dan Sri Rahayu Tri Astuti.(2013). Analisis Pengaruh Kualitas Produk, Harga, Lokasi Dan Kualitas Pelayanan Terhadap Minat Beli Ulang Konsumen (Studi pada Warung Makan "Bebek Gendut" Semarang) Diponegoro. Journal of Management. 2(3), hal. 1-11.

Hume, M. and Gillian, S.M. (2008). Satisfaction in Performing Arts The Role of Value.European Journal of Marketing. 42(3), pp. 311-326.

Hellier, Philip K; Goursen, Gus M; Carr, Rodney A; Rickard, John A. (2003). "Customer Repurchase Intention A General Structural Equation Model." European journal of marketing. 11(12), pp. 1762-1800.

Jen, William and Kai-Chen Hu. (2003). Application of perceivedvalue model to identify factors affecting passenger's repurchase intentions on city bus: A case of the Taipei metropolitan area. Kluwer Academic Publisher. 30(1), pp. 307-327.

Kim, Changsu,. Galliers, Robert D., Ryood, Joo-Han,. Shinc, Namchul and Kime, Jongheon. (2012). Factors Influencing Internet Shopping Value and 
Customer Repurchase Intention. Electronic Commerce Research and Applications. 11(4), pp. 374-387.

Komaling, Ivone Susan dan Alit Suryani.(2017).Peran Kepercayaan dalam Memediasi Kualitas Pelayanan dengan Niat Menggunakan Kembali (Studi Pada Konsumen Blue Bird).E-Jurnal Manajemen Unud. 6(12), hal. 67936817.

Kotler, Philip.(2002). Manajemen Pemasaran di Indonesia: Analisis, Perencanaan, Implementasi dan Pengendalian. Jakarta: Salemba Empat.

Lin, C. and Lekhawipat, W. (2014). Factors affecting online repurchase intention. Industrial Management \& Data Systems. 114(4), pp. 597-611.

Manjunath, S.J., and Aluregowda. (2013). Impact of Services Quality on Customer Satisfaction at AXIS Bank. International Journal of Management and Social Sciences Research (IJMSSR). 2(3), pp. 63-69.

Mardikawati W., dan Farida. (2013). Pengaruh Nilai Pelanggan dan Kualitas Layanan Terhadap Loyalitas Pelanggan, Melalui Kepuasan Pelanggan Pada Pelanggan Bus Efisiensi.Jurnal Administrasi Bisnis. 2(1), hal. 64-75.

Raza Muhammad, Ahmad Nabel Sidiqquei, Hayat M.Awan, Khurram Bukhari. (2012). Relationship Between Service Quality, Perceived Value, Satisfaction And Revisit Intention in Hotel Industry. Interdisclipinary Journal of Contemporary Research in Business. 4(8). 788-805.

Saidani, Basrah dan Samsul Arifin. (2012). Pengaruh Kualitas Produk dan Kualitas Pelayanan Terhadap Kepuasan Kosumen dan Minat Beli Pada Ranch Market. Jurnal Riset Manajemen Sains Indonesi. 3(1), hal. 1-22.

Siyamtinah dan Hendar. (2015). Meningkatkan Pembelian Ulang Melalui Kepercayaan dan Kepuasan Kepada Pembelanjaan Online. Jurnal Akuntansi Bisnis dan Manajemen. 2(1), hal. 435-448.

Singh, A.P. and Thakur, Satendra. (2012). Impact Of Service Quality On Customer Satisfaction and Loyalty: In The Context Of Retail Outlets In DB City Shopping Mall Bhopal. Journal Of Management Research And Review. 2(2), pp. 334-344.

Suariedewi, I Gusti Agung Ayu Mas, dan Eka Sulistyawati.(2016). Peran Perceived Value dalam memediasi Kualitas Pelayanan terhadap Kepuasan Konsumen.E-Jurnal Manajemen Unud. 5(12), hal. 8199-8226.

Sujana, Kadek Ciptadi dan Suprapti, Ni Wayan Sri. (2016). Peran Kepercayaan Dalam Memediasi Kualitas Situs Terhadap Niat Konsumen untuk Berbelanja di Situs Zalora. E-Jurnal Manajemen Unud. 5(1), hal. 595-622. 
Suprapti, Ni Wayan Sri. (2010). Perilaku Konsumen. Denpasar: Udayana University Press.

Suryadharma. Widya, Nurcahya. Ketut.(2015). Pengaruh Kualitas Pelayanan Pada Kepuasan Pelanggan Hotel Bintang Pesona di Denpasar Timur. EJurnal Manajemen Unud, 4(4).

Solvang, Bernt Krohn. (2007). Satisfaction, Loyalty, and Repurchase: A Study of Norwegian Customers of Furniture and Grocery Stores.Journal of Consumer Satisfaction, Dissatisfaction and Complaining Behaviour. 2(1), pp. 110-122.

Wulandari, Luh Putu Sari dan Ni Wayan Ekawati.(2015). Peran Kepercayaan dalam Memediasi Persepsi Nilai terhadap Niat Beli Produk Ramah Lingkungan.E-Jurnal Manajemen Unud. 4(7), hal. 2095-2109.

Wendha, AA Ayu Atika Paramitha; Rahyuda, I Ketut; dan Suasana, I Gst Ketut Gede. (2013). Pengaruh Kualitas Pelayanan terhadap Kepuasan dan Loyalitas Pelanggan Garuda Indonesia di Denpasar. Jurnal Manajemen, Strategi Binsis dan Kewirausahaan. 7(3), hal. 19-28.

Wen, C., Prybutok, V.R., and Xu, C. (2011). An integrated model for customer online repurchase intention. Journal of Computer Information Systems.52 (1), pp. 14-23. 